\title{
STEGANALISIS SINYAL WICARA BERFORMAT .WAV MENGGUNAKAN KOMBINASI METODE MEL-FREQUENCY CEPSTRAL COEFFICIENT (MFCC) DAN LINEAR DISCRIMINANT ANALYSIS (LDA)
}

\author{
Alifia Putri Anantha ${ }^{1}$, Bambang Hidayat ${ }^{2}$, Nur Andini $^{3}$ \\ 1, 2, ${ }^{3}$ Fakultas Teknik Elektro, Universitas Telkom, Bandung 40257, Indonesia \\ 19ananthafia@student.telkomuniversity.ac.id, ${ }^{2}$ bhidayat@telkomuniversity.ac.id, \\ 3 nurandini@telkomuniversity.ac.id
}

\begin{abstract}
Abstrak
Dalam penelitian ini, telah dirancang sebuah sistem yang dapat melakukan steganalisis suatu berkas sinyal wicara berformat .wav, dengan menganalisis karakteristik ciri suatu file speech. Metode yang digunakan untuk mengekstraksi ciri sinyal wicara adalah Mel-Frequency Cepstral Coefficient (MFCC), sedangkan untuk menyeleksi ciri digunakan metode Linear Discriminant Analysis (LDA) metode yang digunakan untuk menyeleksi ciri adalah Linear Discriminant Analysis (LDA). Hasil keluaran dari sistem ini berupa kondisi yang menyatakan berkas sinyal wicara merupakan berkas sinyal wicara asli, tersisip pesan tersembunyi, atau tersisip noise. Support Vector Machine (SVM) digunakan untuk pengklasifikasian dan performansi sistem terbaik yang didapatkan adalah 82,86\%. Kondisi tersebut diraih oleh penggunaan hamming window, overlapping, panjang frame $30 \mathrm{ms,} \mathrm{dan}$ mel-filter bank yang dibangun berjumlah 20 mel-filter bank.
\end{abstract}

Kata Kunci: $\quad$ steganalisis, speech signal, wav, mel-frequency cepstral coefficient, linear discriminant analysis

\section{Abstract}

In this research, it has been designed a system that can steganalize a .wav format speech file, by analyzing the values or characteristics of the speech signal. In order to know characteristics of the signal, Mel-Frequency Cepstral Coeficient (MFCC) and Linear Discriminant Analysis (LDA) were used. The system output is capable to differentiate whether the speech signals is original, contains hidden message, or contains noise. Support Vector Machine (SVM) was used for classification process and the capability of classification of this system is $82.86 \%$. This condition is achieved by the use of hamming window, overlapping, $30 \mathrm{~ms}$ frame length, and 20 bank mel-filters.

Key Words: steganalysis, speech signal, .wav, mel-frequency cepstral coefficient, linear discriminant analysis

\section{Pendahuluan}

Di dunia yang kini serba digital, pertukaran informasi/data sangatlah mudah dan cepat. Dibalik berkembangnya kemudahan pertukaran data, muncul pula beragam teknik yang mampu menyisipkan atau menyembunyikan pesan rahasia ke dalam suatu media, sehingga keberadaan pesan tersebut tidak dapat diketahui oleh banyak pihak. Metode ini disebut steganografi [1]. Permasalahan yang dihadapi adalah, tidak selamanya pesan rahasia yang disisipkan bersifat baik. Maka dari itu diperlukan, suatu upaya untuk mengawasi pendistribusian pesan yang dapat mendeteksi ada tidaknya pesan rahasia yang disembunyikan ke dalam suatu media. Teknik tersebut dinamakan steganalisis [2].

Salah satu media komunikasi digital yang populer di kalangan masyarakat adalah audio berupa sinyal wicara seperti voice note, sehingga kemungkinan adanya pendistribusian pesan rahasia melalui media audio sinyal wicara ini sangatlah besar. Selain itu, perbedaan antara sinyal wicara yang asli dengan yang sudah tersisipi pesan rahasia pun tidak mudah diketahui.

Penelitian ini membahas perancangan sistem steganalisis pada berkas sinyal wicara (speech file) berformat .wav menggunakan metode Mel-Frequency Cepstral Coefficient (MFCC) dan Linear Discriminant Analysis (LDA). MFCC dipilih karena metode ini merupakan metode yang paling populer digunakan untuk mengekstraksi speech file [3][3] dan LDA dipilih karena memiliki error yang kecil [4]. Support Vector Machine (SVM) digunakan dalam proses klasifikasi, karena dalam penentuan jaraknya menggunakan support vector sehingga proses komputasi menjadi cepat [5]. 
MFCC sebelumnya pernah digunakan pada penelitian [1] dan LDA sendiri digunakan pada penelitian [6]. Keduanya sama-sama merancang sistem steganalisis audio dengan akurasi masing-masing 50\% [8] dan $88,33 \%$ [16]. Penelitian ini akan menggunakan kombinasi dari kedua metode tersebut untuk mengetahui distribusi nilai dari ciri berkas sinyal wicara yang dideteksi. Dengan mengetahui nilai-nilai tersebut, maka dapat diketahui perbedaan berkas sinyal wicara asli dengan yang sudah disisipi pesan rahasia, atau bahkan hanya terkena noise.

\section{Dasar Teori}

\subsection{Steganografi}

Secara umum, steganografi biasa didefinisikan sebagai seni menyembunyikan informasi rahasia dalam pesan lain yang tampaknya tidak berbahaya, sehingga mencegah adanya tindakan pendeteksian pesan tersembunyi [7]. Dibandingkan teknik enkripsi lain seperti kriptografi, steganografi merupakan teknik yang lebih efektif untuk meningkatkan keamanan pesan selama proses transfer data [8]. Menggunakan teknik kriptografi, kecurigaan pihak ketiga terhadap pesan yang dikirimkan akan tetap timbul, namun tidak jika menggunakan teknik steganografi [2]. Ada dua komponen utama yang dibutuhkan steganografi, yaitu media carrier dan data rahasia yang ingin disembunyikan. Media carrier berperan sebagai wadah penampung untuk menyisipkan pesan rahasia. Media carrier yang digunakan biasanya berupa media penyimpanan seperti teks, gambar, audio, dan video. Proses steganografi dapat dilihat pada Gambar 1.

\subsection{Steganalisis}

Pengertian steganalisis mengacu pada seni dan ilmu pengetahuan yang membedakan antara stego object dengan cover object atau bisa disebut stego file dengan non-stego file [2]. Maka dari itu, steganalisis dapat dimanfaatkan untuk mengetahui ada atau tidaknya pesan tersembunyi yang terkandung di dalam suatu media, dengan melihat adanya perubahan-perubahan ciri yang terjadi pada media tersebut.

Steganalisis dapat dilakukan pada berbagai jenis media seperti teks, audio/suara, gambar, dan video [2]. Sehebat apapun metode yang digunakan, jejak statistika penyisipan pasti akan tetap terekam. Sehingga, steganalisis pada umumnya dilakukan dengan cara membandingkan media yang menjadi suspect dengan media yang asli. Apabila ditemukan perbedaan diantara keduanya maka dapat ditarik kesimpulan bahwa mungkin terdapat pesan rahasia di dalamnya. Tahapan metode global dalam steganalisis adalah sebagai berikut [6][9]:

1. Membersihkan noise pada media (de-noising).

2. Mengekstraksi feature-feature yang ada.
3. Menganalisa perbedaan atau perubahan yang terjadi antara stego file dengan media aslinya (non-stego file) yang dapat dilihat dari karakteristik cirinya.

4. Menganalisa ciri yang telah diperoleh.

5. Mengklasifikasikan stego file dan file asli dengan melihat pola yang digunakan.

\subsection{Noise}

Pengertian noise menurut Kamus Besar Bahasa Inggris-Amerika adalah suara atau bunyi yang keras, tidak menyenangkan, tidak terduga, atau tidak diinginkan [13]. Menurut ilmu fisika, noise didefinisikan sebagai sebuah gangguan acak, terus menerus, dan mengaburkan kejelasan sinyal [10]. Noise dikarakterisasikan melalui waktu dan frekuensi. Domain waktu, noise dapat berupa continuous dan discontinuous Sementara dalam frekuensi, noise dapat dikategorikan berupa broad band dan narrow band [11].

Bergantung pada karakteristik frekuensi, spektrum atau waktunya, proses noise dikelompokkan menjadi beberapa kategori, yaitu band-limited white noise, white noise, colored noise, narrowband noise, transient noise pulses, dan impulsive noise [12].

\subsection{Mel-Frequency Cepstral Coefficient (MFCC}

Speech signal atau sinyal wicara terdiri dari nada (tone) dengan frekuensi yang berbeda-beda dan dapat didefinisikan secara subjektif pada skala non linier, skala ini dikenal sebagai skala Mel. Skala Mel adalah skala logaritmik frekuensi yang didasarkan pada persepsi pitch atau suara manusia [13]. Mel-Frequency Cepstral Coefficients (MFCC) adalah salah satu teknik ekstraksi fitur paling populer yang digunakan dalam pengenalan suara berdasarkan domain frekuensi menggunakan skala Mel yang diadaptasi pada rentang frekuensi skala pendengaran manusia.

MFCC merupakan representasi dari cepstral nyata dari sinyal short-time yang telah di-windowing yang diturunkan dari transformasi Fast Fourier Transform (FFT) dari sinyal tersebut. Penyebab cepstral nyata ini berbeda adalah skala frekuensi non linier digunakan, sehingga dapat mendekati frekuensi pendengaran manusia. Selain itu, koefisien-koefisien ini kuat dan dapat diandalkan untuk berbagai macam variasi sesuai dengan kondisi pembicara dan perekaman [3].

\subsubsection{Frame Blocking}

Frame Blocking adalah proses pemotongan sinyal suara menjadi beberapa bagian sehingga memudahkan perhitungan dan analisa suara. Setiap potongan-potongan dari sinyal suara tersebut disebut frame. Setiap frame terdiri dari beberapa sampel tergantung waktu suara akan disampel dan berapa besar frekuensi sampling-nya [14]. 


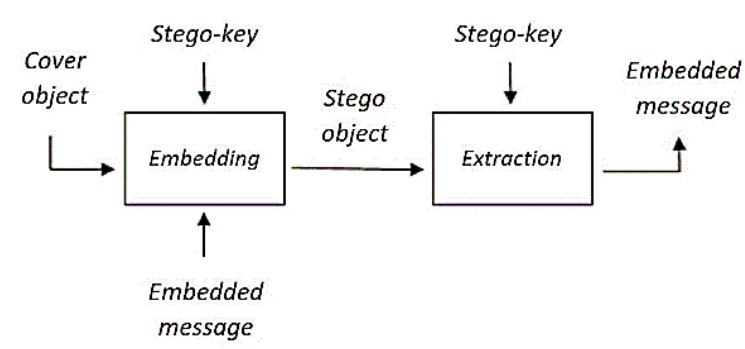

Gambar 1. Proses Steganografi
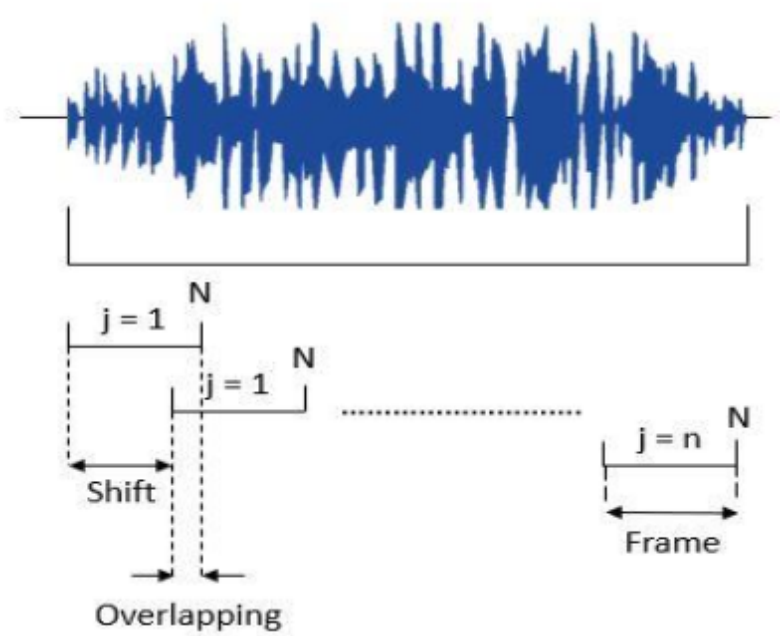

Gambar 2. Frame Blocking pada MFCC [15]

Gambar 2 menunjukkan bahwa sinyal suara dibagi menjadi beberapa frame dan saling bertumpang tindih (overlapping). Overlapping dilakukan untuk memperlancar transisi dari frame ke frame sehingga menghindari adanya kehilangan ciri pada perbatasaan perpotongan setiap frame. Panjang daerah overlap yang digunakan kurang lebih $30-50 \%$ dari panjang frame. Frame pada umumnya memiliki panjang antara $1030 \mathrm{~ms}$ [15].

\subsubsection{Windowing}

Frame blocking dapat menyebabkan terjadinya aliasing atau menyebabkan terjadinya diskontinuitas sinyal. Untuk mengurangi kemungkinan terjadinya efek-efek tersebut, maka setelah melalui proses frame blocking sinyal suara harus melewati proses windowing.

Windowing dilakukan pada setiap frame dengan tujuan untuk meminimalisir diskontinuitas antar dua frame yang berbatasan, khususnya pada bagian awal dan akhir [4]. Fungsi windowing yang paling sering digunakan dalam aplikasi speech recognition adalah hamming dan hanning window, dikarenakan keduanya memiliki karakteristik yang hampir sama.

\subsubsection{Fast Fourier Transform (FFT)}

FFT adalah salah satu metode untuk mengubah sinyal suara dari domain waktu menjadi domain frekuensi. Artinya, proses perekaman suara disimpan dalam bentuk digital berupa gelombang spektrum suara berbasis frekuensi yang kemudian menghasilkan pendeteksian gelombang frekuensi domain dalam bentuk diskrit [15]. FFT merupakan transformasi turunan dari Discrete Fourier Transform (DFT), dimana jumlah perhitungan digital pada DFT dapat dikurangi secara signifikan. Sehingga, perhitungan digital terhadap spektrum-spektrum frekuensi pada FFT dapat diwujudkan secara sederhana dalam pengimplementasiannya.

\subsubsection{Mel-Frequency Wrapping}

Mel-Frequency Wrapping biasanya dilakukan menggunakan filter bank. Filter bank adalah salah satu bentuk dari filter yang dilakukan dengan tujuan untuk mengetahui ukuran energi dari frequency band tertentu dalam sinyal suara. Pada MFCC, filter bank diterapkan dalam domain frekuensi.

Dalam penelitian [3], hubungan antara frekuensi bicara dengan skala Mel dapat ditetapkan seperti persamaan (1).

$$
\text { Frekuensi }(\text { Mel scaled })=\left(2595 \log \left(\frac{1+f(\mathrm{~Hz})}{700}\right)\right)
$$

MFCC menggunakan Mel-scale filter bank dimana filter frekuensi yang lebih tinggi memiliki bandwidth yang lebih besar daripada frekuensi filter yang lebih rendah, tetapi resolusi temporal yang dimiliki keduanya sama [3].

\subsubsection{Cepstrum}

Cepstrum merupakan kebalikan dari spectrum. Spectrum merupakan kondisi ketika sinyal dianalisis dalam domain waktu, sedangkan cepstrum merupakan kondisi ketika sinyal dianalisis dalam domain frekuensi dan amplitudo dari sinyal tersebut diambil untuk menganalisis sinyal. Cepstrum biasa dipergunakan untuk mendapatkan suatu informasi dari sinyal suara yang diucapkan oleh manusia. Pada langkah terakhir ini, spektrum log-mel (output dari filter bank) dikonversi ke dalam domain waktu menjadi cepstrum menggunakan sebuah transformasi bernama Discrete Cosine Transform (DCT) [4]. DCT merentangkan koefisien-koefisien sesuai dengan signifikansi, dimana koefisien ke-0 dikecualikan karena sifatnya yang unreliable (tidak dapat diandalkan) [3]. Hasil dari proses inilah yang dinamakan dengan Mel-Frequency Cepstrum Coefficients (MFCC). 


\subsection{Linear Discriminant Analysis (LDA)}

Linear Discriminant Analysis (LDA) merupakan metode yang terkenal untuk memperkirakan atau mengestimasi sub-ruang linier dengan sifat diskriminatif yang baik. LDA telah banyak digunakan baik dalam klasifikasi sinyal wicara maupun gambar [13]. Prinsipnya adalah untuk menemukan proyeksi data, dimana varians antara kelas-kelas itu lebih besar dibandingkan dengan varians di dalam kelas [17]. Sehingga, prinsip dasarnya adalah menemukan sebuah transformasi linear sehingga pengklasteran dapat dipisahkan setelah transformasi. Tujuan LDA adalah untuk menemukan transformasi optimal dengan cara meminimalkan jarak di dalam kelas (within-class distance) dan memaksimalkan jarak antar kelas (between-class distance) secara bersamaan, sehingga didapatkan diskriminasi yang maksimal.

\subsection{Support Vector Machine (SVM)}

Support Vector Machine (SVM) merupakan suatu teknik yang dapat melakukan prediksi, baik dalam kasus klasifikasi maupun regresi. SVM masuk ke dalam kategori supervised learning, dimana dalam pengimplementasiannya memerlukan tahap training dan tahap testing [18]. SVM adalah metode lokal yang solusinya ditentukan secara eksklusif oleh vektor pendukung (support vector) sedangkan semua titik data lainnya tidak relevan dengan keputusan hyperplane [19]. Sehingga prinsip kerja SVM adalah menemukan fungsi pemisah (hyperplane) yang optimal, sehingga dapat memisahkan beberapa set data dari beberapa buah kelas yang berbeda pada input space secara maksimal.

\section{Desain Model Sistem}

Sistem steganalisis yang dirancang pada penelitian ini terdiri dari dua tahap, yaitu tahap pelatihan dan pengujian. Blok diagram perancangan model sistem pada data latih dan data uji ditunjukkan pada Gambar 3.

Pada tahap pelatihan, data sinyal wicara dimasukkan ke dalam perangkat, kemudia melalui proses MFCC dan LDA, yang keluarannya dijadikan data latih dan disimpan di dalam database latih. Sedangkan pada tahap pengujian, data uji dimasukkan ke dalam perangkat dan melalui proses yang sama seperti tahap pelatihan hingga proses LDA. Hanya saja setelah proses seleksi ciri, ciri latih yang telah disimpan di database saat proses pelatihan, digunakan sebagai ciri pembanding pada tahap klafisikasi. Adapun penjelasan dari setiap tahap pada konfigurasi sistem dapat diuraikan sebagai berikut:

1. Berkas sinyal wicara diekstraksi cirinya menggunakan MFCC, dimana di dalamnya terjadi transformasi FFT, yang berfungsi sebagai pengubah sinyal dari domain waktu ke domain frekuensi. Setelah melewati pengolahan, transformasi inverse FFT dilakukan, atau biasa
Tabel 1. Nilai SNR pada Speech Noise

\begin{tabular}{|c|c|}
\hline Nama File & $\begin{array}{c}\text { Nilai Signal } \\
\text { to Noise Ratio (SNR) }\end{array}$ \\
\hline Noise_AWGN-06 & $11,9232 \mathrm{~dB}$ \\
\hline Noise_AWGN-07 & $13,5325 \mathrm{~dB}$ \\
\hline Noise_AWGN-08 & $7,2717 \mathrm{~dB}$ \\
\hline Noise_AWGN-09 & $17,1019 \mathrm{~dB}$ \\
\hline Noise_AWGN-10 & $20,6797 \mathrm{~dB}$ \\
\hline Noise_Echo-06 & $14,8303 \mathrm{~dB}$ \\
\hline Noise_Echo-07 & $13,3948 \mathrm{~dB}$ \\
\hline Noise_Echo-08 & $7,1612 \mathrm{~dB}$ \\
\hline Noise_Echo-09 & $17,8911 \mathrm{~dB}$ \\
\hline Noise_Echo-10 & $16,5837 \mathrm{~dB}$ \\
\hline Noise_Gauss-06 & $30,8798 \mathrm{~dB}$ \\
\hline Noise_Gauss-07 & $30,4278 \mathrm{~dB}$ \\
\hline Noise_Gauss-08 & $28,9338 \mathrm{~dB}$ \\
\hline Noise_Gauss-09 & $29,8252 \mathrm{~dB}$ \\
\hline Noise_Gauss-10 & $29,0955 \mathrm{~dB}$ \\
\hline
\end{tabular}

disebut DCT yang mengubah sinyal dari domain frekuensi menjadi domain waktu kembali. Output yang didapatkan dari proses ini berupa koefisien Mel-Frequency Cepstrum.

2. Hasil keluaran dari MFCC yang sudah berupa koefisien Mel-Frequency Cepstrum kemudian diseleksi cirinya menggunakan metode LDA. Tujuannya adalah untuk mengoptimalkan nilai diskriminan serta mempercepat proses pengujian.

3. Setelah dilakukan ekstraksi dan seleksi ciri, pengklasifikasian menggunakan metode SVM dilakukan, guna memisahkan beberapa set data dari kelas asli, noise, dan stego secara maksimal. Hal tersebut dilakukan dengan cara mencari hyperplane terbaik dari yang ada.

4. Jika hasil klasifikasi telah didapatkan, maka dapat dilakukan pengambilan keputusan dan proses steganalisis selesai.

\section{Pengujian dan Analisis Sistem}

Pengujian dilakukan menggunakan 15 buah data speech berformat wav yang masing-masing berdurasi 10 detik. Data speech tersebut kemudian dikelompokkan menjadi 5 audio per kelompok untuk audio asli, penyisipan stego, dan penyisipan noise. Masing-masing data speech pada kelompok stego disisipi pesan rahasia dengan metode penyisipan LSB, DCT, dan DWT. Selain itu, masing-masing data speech pada kelompok noise juga disisipi tiga jenis noise, yaitu gaussian, Additive White Gaussian Noise (AWGN), dan echo. Gaussian noise merupakan noise yang mengikuti distribusi normal dan white noise adalah sinyal dengan energi yang sama pada semua frekuensi.

Biasanya akan sangat sulit menemukan contoh white 


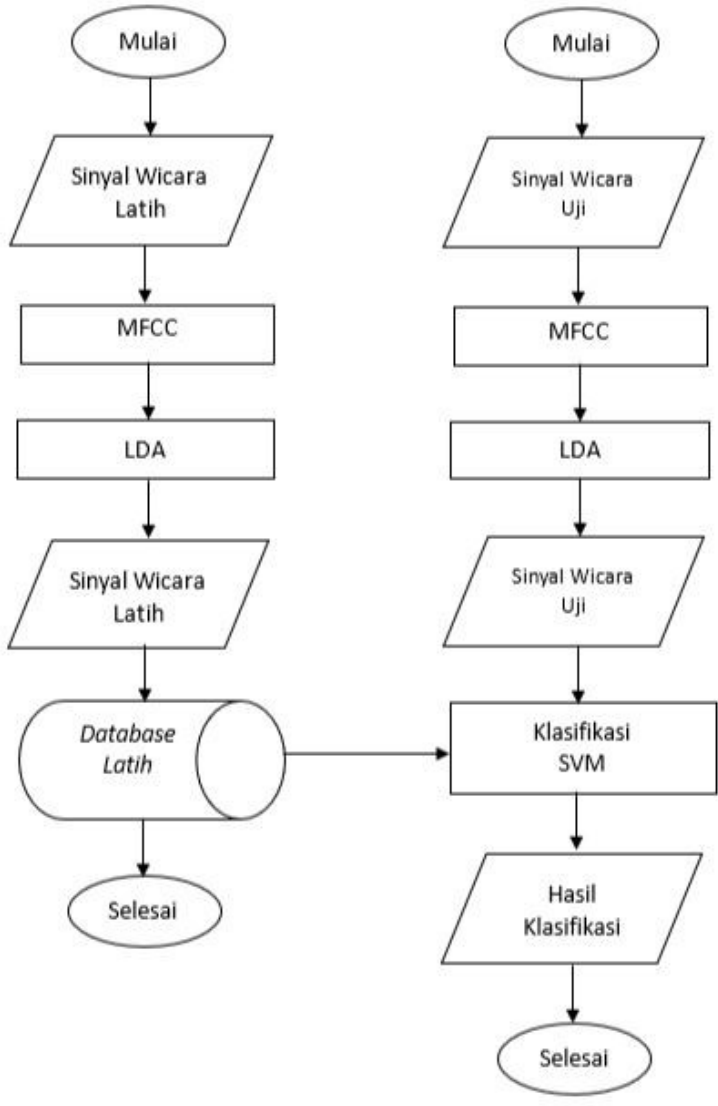

Gambar 3. Blok Diagram Perancangan Sistem Steganalisis

Tabel 2. Pengaruh Jenis Fungsi Windowing pada SVM Tahap 1

\begin{tabular}{|c|c|c|}
\hline \multicolumn{3}{|c|}{ HAMMING } \\
\hline No. & Kelas Audio & Akurasi \\
\hline 1 & Asli & $100 \%$ \\
\hline 2 & Bukan Asli & $100 \%$ \\
\hline \multicolumn{2}{|c|}{ Akurasi Data Keseluruhan } & $100 \%$ \\
\hline \multicolumn{3}{|c|}{ HANNING } \\
\hline No. & Kelas Audio & Akurasi \\
\hline 1 & Asli & $80 \%$ \\
\hline 2 & Bukan Asli & $100 \%$ \\
\hline \multicolumn{2}{|c|}{ Akurasi Data Keseluruhan } & $97,14 \%$ \\
\hline
\end{tabular}

noise yang tidak gaussian. Nilai Signal to Noise Ratio (SNR) pada setiap speech file uji yang tergolong dalam kelompok noise dapat dilihat pada Tabel 1.

Jumlah keseluruhan data speech yang digunakan pada pengujian ini adalah 35 , dengan spesifikasi 5 data asli, 15 data noise, dan 15 data stego. Klasifikasi SVM dilakukan melalui 2 tahap, pertama memisahkan dan mengklasifikasikan audio uji menjadi speech asli dan speech bukan asli dan kedua memisahkan dan
Tabel 3. Pengaruh Jenis Fungsi Windowing pada SVM Tahap 2

\begin{tabular}{|c|c|c|}
\hline \multicolumn{3}{|c|}{ HAMMING } \\
\hline No. & Kelas Audio & Akurasi \\
\hline 1 & Asli & $100 \%$ \\
\hline 2 & Noise & $93,33 \%$ \\
\hline 3 & Stego & $66,67 \%$ \\
\hline Akurasi Data Keseluruhan & $82,86 \%$ \\
\hline \multicolumn{3}{|c|}{ HANNING } \\
\hline No. & Kelas Audio & Akurasi \\
\hline 1 & Asli & $80 \%$ \\
\hline 2 & Noise & $93,33 \%$ \\
\hline 3 & Stego & $73,33 \%$ \\
\hline \multicolumn{2}{|c|}{ Akurasi Data Keseluruhan } & $82,86 \%$ \\
\hline
\end{tabular}

Tabel 4. Pengaruh Overlap pada SVM Tahap 1

\begin{tabular}{|c|c|c|}
\hline \multicolumn{3}{|c|}{ OVERLAP } \\
\hline No. & Kelas Audio & Akurasi \\
\hline 1 & Asli & $100 \%$ \\
\hline 2 & Bukan Asli & $100 \%$ \\
\hline Aku & Data Keseluruhan & $100 \%$ \\
\hline \multicolumn{3}{|c|}{ NON-OVERLAP } \\
\hline No. & Kelas Audio & Akurasi \\
\hline 1 & Asli & $40 \%$ \\
\hline 2 & Bukan Asli & $93,33 \%$ \\
\hline \multicolumn{2}{|r|}{ Data Keseluruhan } & $85,71 \%$ \\
\hline
\end{tabular}

Tabel 5. Pengaruh Overlap pada SVM Tahap 2

\begin{tabular}{|c|c|c|}
\hline \multicolumn{3}{|c|}{ OVERLAP } \\
\hline No. & Kelas Audio & Akurasi \\
\hline 1 & Asli & $100 \%$ \\
\hline 2 & Noise & $93,33 \%$ \\
\hline 3 & Stego & $66,67 \%$ \\
\hline Aku & Data Keseluruhan & $82,86 \%$ \\
\hline \multicolumn{3}{|c|}{ NON-OVERLAP } \\
\hline No. & Kelas Audio & Akurasi \\
\hline 1 & Asli & $40 \%$ \\
\hline 2 & Noise & $100 \%$ \\
\hline 3 & Stego & $33,33 \%$ \\
\hline \multicolumn{2}{|c|}{ Akurasi Data Keseluruhan } & $62,86 \%$ \\
\hline
\end{tabular}

mengklasifikasikan audio uji yang tergolong bukan asli menjadi speech stego dan speech noise.

Performansi sistem dapat dilihat dari hasil akurasi sistem, yang mendeklarasikan bahwa setiap berkas sinyal wicara terdeteksi benar. Persamaan akurasi dapat ditulis dengan persamaan (2):

$$
\text { Akurasi }=\frac{\text { Jumlahdatabenar }}{\text { Jumlah seluruhdata }} \times 100 \%
$$




\subsection{Analisis Pengaruh Jenis Fungsi Windowing Terhadap Akurasi}

Menurut teori, fungsi windowing yang paling sering digunakan dalam aplikasi speech recognition adalah hamming window dan hanning window. Keduanya sama-sama memiliki fungsi untuk mengurangi terjadinya diskontinuitas pada sinyal setelah terjadi proses frame blocking. Maka dari itu, dilakukan penelitian untuk mengetahui fungsi windowing mana yang dapat menghasilkan akurasi yang lebih baik. Perbandingan hasil akurasi dapat dilihat pada Tabel 2 dan Tabel 3. Hasil akhir yang menjadi acuan pada penelitian ini dalam menentukan berhasil tidaknya sistem adalah hasil keluaran SVM tahap 2 yang sudah berupa apakah data audio yang diuji tergolong asli, windowing, atau windowing.

Dengan melihat hasil akurasi akhir kedua fungsi windowing dapat disimpulkan bahwa keduanya sama baik, dikarenakan sama-sama memiliki akurasi $82,86 \%$.

\subsection{Analisis Pengaruh Overlap Terhadap Akurasi}

Menurut penjelasan pada penelitian [18], overlapping dilakukan untuk memperlancar transisi dari frame ke frame, sehingga menghindari adanya kehilangan ciri pada perbatasaan perpotongan setiap frame. Maka dari itu, dilakukan studi untuk membuktikan tindakan mana yang dapat menghasilkan akurasi yang lebih baik. Dalam kondisi ini, speech file yang memiliki panjang 480.000 samples di-overlap dengan koreksi nilai M sebesar 100 samples, sehingga dalam satu audio terdapat 4786 frames, yang masing-masing frame-nya terdiri dari 1440 samples. Sementara, jumlah frame pada audio yang tidak melalui proses overlap adalah 334 . Hasil akurasi pengaruh overlap pada SVM Tahap 1 dan Tahap 2, masing-masing dapat dilihat pada Tabel 4 dan Tabel 5 secara berturut-turut.

Dari hasil tersebut, dapat dilihat pengaruh ada tidaknya overlapping pada proses frame blocking terhadap akurasi sistem. Pada audio uji, steganalisis dengan menggunakan proses overlap memiliki akurasi yang lebih tinggi dibandingkan dengan yang tidak menggunakan proses overlap. Hal ini membuktikan bahwa overlapping pada sampel mampu mengurangi risiko adanya kehilangan ciri.

\subsection{Analisis Pengaruh Panjang Frame Terhadap Akurasi}

Dalam penelitian ini, dilakukan analisis pengaruh panjang frame terhadap akurasi sistem steganalisis yang didapatkan. Audio asli, serta audio yang telah disisipi noise dan pesan rahasia akan di-framing dengan tiga panjang frame yang berbeda yaitu $30 \mathrm{~ms}, 60 \mathrm{~ms}$, dan 90 ms. Audio latih dan audio uji kemudian dibandingkan dengan panjang frame tersebut untuk melihat
Tabel 6. Pengaruh Panjang Frame pada SVM Tahap 1

\begin{tabular}{|c|c|c|}
\hline \multicolumn{3}{|c|}{$30 \mathrm{~ms}$} \\
\hline No. & Kelas Audio & Akurasi \\
\hline 1 & Asli & $100 \%$ \\
\hline 2 & Bukan Asli & $100 \%$ \\
\hline Akurasi Data Keseluruhan & $100 \%$ \\
\hline \multicolumn{3}{|c|}{$60 \mathrm{~ms}$} \\
\hline No. & Kelas Audio & Akurasi \\
\hline 1 & Asli & $40 \%$ \\
\hline 2 & Bukan Asli & $100 \%$ \\
\hline Akurasi Data Keseluruhan & $91,43 \%$ \\
\hline \multicolumn{3}{|c|}{$90 \mathrm{~ms}$} \\
\hline No. & Kelas Audio & Akurasi \\
\hline 1 & Asli & $40 \%$ \\
\hline 2 & Bukan Asli & $100 \%$ \\
\hline Akurasi Data Keseluruhan & $91,43 \%$ \\
\hline
\end{tabular}

performansi sistem. Hasil akurasi dapat dilihat pada Tabel 6 dan Tabel 7.

Dari hasil tersebut dapat dilihat bahwa semakin panjang suatu frame, maka semakin rendah akurasi yang didapat. Hal ini dapat terjadi dikarenakan adanya perbedaan banyak ciri sampling.

\subsection{Analisis Pengaruh Jumlah Mel-Filter Bank Terhadap Akurasi}

Menurut teori, jumlah mel-filter bank yang biasanya digunakan adalah berkisar pada angka 20-40. Maka dari itu, dilakukan penelitian untuk mengetahui berapa jumlah mel-filter bank yang dapat menghasilkan tingkat akurasi yang lebih baik. Hasil akurasi dapat dilihat pada Tabel 8 dan Tabel 9.

Dari hasil tersebut dapat kita lihat bahwa semakin banyak jumlah mel-filter bank yang dibangun pada tahap mel-frequency wrapping, maka semakin rendah tingkat akurasi yang didapat.

\section{Kesimpulan}

Berdasarkan hasil perancangan dan analisa sistem steganalisis dapat diambil beberapa kesimpulan sebagai berikut:

1. Sistem steganalisis menggunakan metode Mel-Frequency Cepstral Coefficient dan Linear Discriminant Analysis mampu membedakan audio asli, audio noise, dan audio stego secara baik meskipun belum sepenuhnya maksimal.

2. Dari keempat parameter yang diuji, hasil akurasi SVM tahap 1 (memisahkan audio asli dan bukan asli) selalu lebih baik dibandingkan dengan hasil akurasi setelah dilakukan SVM tahap 2 (memisahkan audio stego dan noise). Hal ini 
Tabel 7. Pengaruh Panjang Frame pada SVM Tahap 2

\begin{tabular}{|c|c|c|}
\hline \multicolumn{3}{|c|}{$30 \mathrm{~ms}$} \\
\hline No. & Kelas Audio & Akurasi \\
\hline 1 & Asli & $100 \%$ \\
\hline 2 & Noise & $93,33 \%$ \\
\hline 3 & Stego & $66,67 \%$ \\
\hline Akurasi Data Keseluruhan & $82,86 \%$ \\
\hline \multicolumn{3}{|c|}{$60 \mathrm{~ms}$} \\
\hline No. & Kelas Audio & Akurasi \\
\hline 1 & Asli & $40 \%$ \\
\hline 2 & Noise & $93,33 \%$ \\
\hline 3 & Stego & $53,33 \%$ \\
\hline Akurasi Data Keseluruhan & $68,57 \%$ \\
\hline \multicolumn{3}{|c|}{ 90 ms } \\
\hline No. & Kelas Audio & Akurasi \\
\hline 1 & Asli & $40 \%$ \\
\hline 2 & Noise & $93,33 \%$ \\
\hline 3 & Stego & $40 \%$ \\
\hline Akurasi Data Keseluruhan & $62,86 \%$ \\
\hline \multicolumn{3}{|c|}{}
\end{tabular}

Tabel 8. Pengaruh Jumlah Mel-Filter Bank pada SVM Tahap 1

\begin{tabular}{|c|c|c|}
\hline \multicolumn{3}{|c|}{$30 \mathrm{~ms}$} \\
\hline No. & Kelas Audio & Akurasi \\
\hline 1 & Asli & $100 \%$ \\
\hline 2 & Bukan Asli & $100 \%$ \\
\hline \multicolumn{2}{|c|}{ Akurasi Data Keseluruhan } & $100 \%$ \\
\hline \multicolumn{3}{|c|}{$60 \mathrm{~ms}$} \\
\hline No. & Kelas Audio & Akurasi \\
\hline 1 & Asli & $100 \%$ \\
\hline 2 & Bukan Asli & $63,33 \%$ \\
\hline Akur & Data Keseluruhan & $68,57 \%$ \\
\hline \multicolumn{3}{|c|}{$90 \mathrm{~ms}$} \\
\hline No. & Kelas Audio & Akurasi \\
\hline 1 & Asli & $100 \%$ \\
\hline 2 & Bukan Asli & $20 \%$ \\
\hline \multicolumn{2}{|c|}{ Akurasi Data Keseluruhan } & $31,43 \%$ \\
\hline
\end{tabular}

dikarenakan karakteristik ciri audio stego dan noise yang lebih mirip dibandingkan karakteristik audio asli.

3. Pada sistem steganalisis ini, perbedaan jenis fungsi windowing antara hamming dan hanning window tidak memiliki pengaruh yang terlalu signifikan, dikarenakan keduanya menghasilkan tingkat akurasi yang sama besar.

4. Membagi panjang frame menjadi $30 \mathrm{~ms}$ dan melakukan overlapping sinyal pada tahap frame blocking dapat menghasilkan tingkat akurasi yang lebih baik dikarenakan terminimalisirnya risiko
Tabel 9. Pengaruh Jumlah Mel-Filter Bank pada SVM Tahap 2

\begin{tabular}{|c|c|c|}
\hline \multicolumn{3}{|c|}{$30 \mathrm{~ms}$} \\
\hline No. & Kelas Audio & Akurasi \\
\hline 1 & Asli & $100 \%$ \\
\hline 2 & Noise & $93,33 \%$ \\
\hline 3 & Stego & $66,67 \%$ \\
\hline Akurasi Data Keseluruhan & $82,86 \%$ \\
\hline \multicolumn{3}{|c|}{$60 \mathrm{~ms}$} \\
\hline No. & Kelas Audio & Akurasi \\
\hline 1 & Asli & $100 \%$ \\
\hline 2 & Noise & $60 \%$ \\
\hline 3 & Stego & $20 \%$ \\
\hline Akurasi Data Keseluruhan & $48,57 \%$ \\
\hline \multicolumn{3}{|c|}{$90 \mathrm{~ms}$} \\
\hline No. & Kelas Audio & Akurasi \\
\hline 1 & Asli & $100 \%$ \\
\hline 2 & Noise & $33,33 \%$ \\
\hline 3 & Stego & $0 \%$ \\
\hline Akurasi Data Keseluruhan & $28,576 \%$ \\
\hline
\end{tabular}

kehilangan ciri pada saat pemotongan audio.

5. Dari keseluruhan pengujian, performansi sistem terbaik yang didapatkan adalah $82,86 \%$. Angka tersebut dicapai dengan kondisi audio latih dan audio uji menggunakan hamming window, terdapat overlapping, panjang frame $30 \mathrm{~ms}$, serta jumlah mel-filter bank yang dibangun sebesar 20.

\section{Daftar Pustaka}

[1] N. F. Johnson and S. Jajodia, "Exploring steganography: Seeing the unseen," Computer, vol. 31, no. 2, 1998.

[2] H. Liu, J. Liu, R. Hu, X. Yan, and S. Wan, "Adaptive audio steganography scheme based on wavelet packet energy," in Big Data Security on Cloud (BigDataSecurity), IEEE International Conference on High Performance and Smart Computing (HPSC), and IEEE International Conference on Intelligent Data and Security (IDS), 2017 IEEE 3rd International Conference on. IEEE, 2017, pp. 2631.

[3] N. Dave, "Feature extraction methods lpc, plp and mfcc in speech recognition," International journal for advance research in engineering and technology, vol. 1, no. 6, pp. 1-4, 2013.

[4] S. Erani, B. Hidayat, and S. A. Wibowo, Sistem Identifikasi Suara Pria dan Wanita Berdasarkan Usia Menggunakan Mel Frequency Cepstral Coefficient dan LPC Dengan Metode Klasifikasi SOM, 2011. 
[5] J. Filipus, Perbandingan Digital Steganografi Pada Media Image, Audio, Video dan Teks serta Kekuatannya Terhadap Steganalisis, 2010.

[6] Y. Kurniawan, "Studi metode steganalisis pada stegoimage."

[7] R. Aeri, "Ekstraksi fitur menggunakan metode lda dan pemilihan eigen value pada cacat kertas duplek," Jurnal Simantec, vol. 3, no. 3, p. 142149, Dec 2013.

[8] M. Z. Aminudin, B. Hidayat, and R. F. Umbara, Stegnalisis File Audio dengan Metode Statistik MFCC, 2015.

[9] A. Madan and D. Gupta, "Speech feature extraction and classification: A comparative review," International Journal of computer applications, vol. 90, no. 9, 2014.

[10] M. Murugappan, N. Q. I. Baharuddin, and S. Jerritta, "Dwt and mfcc based human emotional speech classification using lda," in Biomedical Engineering (ICoBE), 2012 International Conference on. IEEE, 2012, pp. 203-206.

[11] J. Pylkkönen, "Lda based feature estimation methods for lvcsr," in Ninth International Conference on Spoken Language Processing, 2006.

[12] B. Santosa, Tutorial Support Vector Machines, 2015.

[13] I. B. Setiawan, T. A. S. Prasida, and M. Bezaleel, "Aplikasi noise reduction untuk perbaikan kualitas suara pada data audio menggunakan algoritma fastica," Jurnal Teknologi Informasi, vol. 8, no. 2.

[14] E. M. Singla and M. H. Singh, "Paper on frequency based audio noise reduction using butterworth, chebyshev \& elliptical filters," Int. J. Recent Innov. Trends Comput. Commun, vol. 3, pp. 5989-5995, 2015.

[15] M. Singla and H. Singh, "Review paper on frequency based audio noise reduction using different filters," International Journal of Science, Engineering and Technology Research (IJSETR), vol. 4, no. 5, p. 14061409, May 2015.

[16] V. I. Sinisuka, "Steganalisis audio format wav menggunakan metode discrete wavelet transform dan linear discriminant analysis," 2017.

[17] C. Cortes and V. Vapnik, "Support-vector networks," Machine learning, vol. 20, no. 3, pp. 273-297, 1995.

[18] A. Wicaksono, S. N. Endah, S. Adhy, and S. Sutikno, "Aplikasi speech recognition bahasa indonesia dengan metode mel-frequency cepstral coefficient dan linear vector quantization untuk pengendalian gerak robot," in Prosiding Seminar Nasional Ilmu Komputer Undip 2014.

[19] T. Xiong and V. Cherkassky, "A combined svm and lda approach for classification," in Neural Networks, 2005. IJCNN'05. Proceedings. 2005 IEEE International Joint Conference on, vol. 3. IEEE, 2005, pp. 1455-1459. 